\title{
STRUKTUR BIAYA DAN PROFITABILITAS USAHATANI TANAMAN PANGAN (Padi, Jagung, dan Kedelai)
}

\author{
The Structure Of The Cost And The Profitability Of The Farming Of The Food Crop \\ (Paddy, Corn, And Soybeans)
}

\author{
Sri Karuniari Nuswardhani ${ }^{1}$ \\ ${ }^{1}$ Fakultas Pertanian, Universitas Yudharta Pasuruan \\ Email: faperta@yudharta.ac.id
}

\begin{abstract}
ABSTRAK
Salah satu cara untuk mengetahui baik dan tidaknya keragaan suatu usahatani adalah dengan mengetahui biaya dan profitabiltasnya. Analisis struktur biaya dan profitabilitas usahatani diperlukan sebagai bahan pertimbangan dalam mengambil keputusan tentang pengembangan komoditas dengan tujuan meningkatkan produksi sekaligus memperbaiki taraf hidup. Penelitian ini bertujuan mengidentifikasi dan menganalisis struktur biaya dan profitabilitas usahatani tanaman pangan. Penelitian ini memanfaatkan data sekunder yang telah dirilis resmi oleh Badan Pusat Statistik (BPS), yaitu Laporan Bulanan Data Sosial Ekonomi dan Struktur Ongkos Usahatani Tanaman Pangan. Untuk Laporan Bulanan Data Sosial Ekonomi adalah publikasi BPS pada bulan Oktober 2016, sedangkan Struktur Ongkos Usahatani tanaman Pangan adalah publikasi BPS pada tahun 2011. Hasil penelitian menunjukkan struktur biaya usahatani ketiga komoditi (padi, jagung, dan kedelai hampir sama). Pada komoditas padi, jagung, dan kedelai pangsa biaya terbesar untuk upah tenaga kerja dan sewa lahan. Pada periode 2011-2014, total biaya usahatani untuk ketiga komoditas tersebut cenderung menurun. Penurunan total biaya ini dominan disebabkan oleh penurunan upah kerja selama periode 20112014, walaupun ada kenaikan sewa lahan, tetapi selisih kenaikannya masih lebih rendah daripada selisih penurunan upah kerja. Secara umum biaya per ha usahatani padi sawah paling besar dibandingkan dengan padi ladang, jagung dan kedelai. Hasil penelitian menunjukkan, bahwa tingkat keuntungan, R/C Ratio, dan efisiensi usahatani padi sawah lebih baik daripada padi ladang, jagung, apalagi kedelai. Usahatani padi sawah, padi ladang, jagung masih layak diusahakan, karena tingkat keuntungan, R/C Ratio dan efisiensi bernilai positif, sedangkan kedelai tidak layak, karena tingkat keuntungan dan efisiensi bernilai negative dan R/C Ratio di bawah 1.

Kata kunci: usahatani, stuktur biaya, profitabilitas, dan efisiensi
\end{abstract}

\section{ABSTRACT}

One way to find out whether the performance of a farm is good or not is to know its costs and profitability. Analysis of cost structure and profitability of farming is needed as a consideration in making decisions about commodity development with the aim of increasing production while improving living standards. This study aims to identify and analyze the cost structure and profitability of food crop farming. This study utilizes secondary data that has been released officially by the Central Statistics Agency (BPS), namely the Monthly Report on Socio-Economic Data and the Food Crop Structure of Food Crops. For the Monthly Report on Socio-Economic Data is the publication of BPS in October 2016, while the Food Structure of Food Crop Farming is a publication of BPS in 2011. The results of the study show the cost structure of farming of the three commodities (rice, corn and soybeans almost the same). In the rice, corn and soybean 
commodities the share of the largest costs for labor wages and land rent. In the 20112014 period, the total farming costs for the three commodities tended to decline. The decrease in total costs was predominantly caused by a decrease in wages during the 2011-2014 period, although there was an increase in land rent, but the difference in the increase was still lower than the difference in the decrease in wage employment. In general, the cost per ha of lowland rice farming is the highest compared to field rice, corn and soybeans. The results showed that the level of profit, $R$ / $C$ ratio, and efficiency of rice farming were better than field rice, corn, especially soybeans. Lowland rice farming, field rice, corn are still viable, because of the level of profit, $R / C$ Ratio and efficiency are positive, while soybeans are not feasible, because the level of profit and efficiency is negative and $R / C$ Ratio is below 1.

Keywords: farming, cost structure, profitability, and efficiency

\section{PENDAHULUAN}

Berusahatani merupakan kegiatan yang dilaksanakan oleh mayoritas penduduk Indonesia yang sebagian besar mempunyai mata pencaharian sebagai petani. Salah satu tujuan berusahatani merupakan upaya untuk mendapatkan produksi, baik untuk tujuan konsumsi dalam memenuhi kebutuhan sehari-hari maupun untuk tujuan dijual dalam rangka meningkatkan pendapatan. Keputusan petani dalam berusahatani banyak dipengaruhi oleh faktor-faktor yang meliputi lingkungan fisik (tanah dan agroklimat), biologi, kondisi pengairan, ketersediaan teknologi, sistem penunjang (modal/kredit, pasar input/output, penyuluhan dan sumber daya petani) (Shanner, 1982).

Pada kenyataannya petani selalu dihadapkan pada berbagai kebutuhan dalam memilih usahatani komoditas yang akan diusahakan, alokasi biaya dan pencapaian keuntungan yang tinggi. Biaya mempunyai peranan yang amat penting dalam pengambilan keputusan usahatani, besarnya biaya yang dikeluarkan untuk memproduksi sesuatu menentukan besarnya harga pokok (biaya per unit) dari produk yang dihasilkan (Soeharjo dan Patong, 1973 dalam Supadi, 2005). Rendahnya pendapatan usahatani erat kaitannya dengan beberapa faktor antara lain aplikasi teknologi, luas penguasaan lahan usaha dan tingkat efisiensi usahatani. Kenaikan harga output yang diterima petani tidak sebanding dengan kenaikan harga input produksi yang harus dibayar, bersama dengan semakin lambatnya peningkatan produktivitas, sehingga berakibat rendahnya tingkat efisiensi dan pendapatan usahatani (Supadi, 2005)

Kelayakan suatu usahatani sangat dipengaruhi oleh faktor teknis, ekonomis, dan sosial. Oleh karena itu, upaya melanggengkan usahatani bukan persoalan yang sederhana. Faktor teknis 
dapat meliputi cara budidaya, tingkat teknologi dan lingkungan baik biotik maupun abiotik. Faktor ekonomi dapat meliputi harga input-ouput, biaya dan pendapatan. Faktor sosial dapat berupa adat istiadat. Petani harus mempertimbangkan tidak hanya dimensi teknis dan ekonomis tetapi juga sosial budaya (Sumaryanto,2004 dalam Supadi, 2005). Analisis biaya dan pendapatan sangat diperlukan sebagai bahan dalam mengambil keputusan mengenai penggunaan teknologi dan didalam memilih prioritas yang paling baik untuk waktu yang akan datang dengan tujuan untuk meningkatkan produksi usahatani dan memperbaiki taraf hidup (Hadisapoetro, 1973 dalam Supadi, 2005). Disamping itu analisis biaya dan pendapatan usahatani sangat diperlukan untuk menentukan kebijaksanaan pemerintah didalam mendorong kegairahan petani untuk meningkatkan produksi usahataninya misalnya didalam menentukan harga dasar, harga sarana produksi dan sebagainya. Profitabilitas usahatani erat kaitannya dengan beberapa faktor antara lain aplikasi teknologi, luas penguasaan lahan usaha, harga input dan harga output. Jika kenaikan harga output yang diterima petani tidak sebanding dengan kenaikan harga input produksi yang harus dibayar petani disertai dengan semakin lambatnya peningkatan produktivitas berakibat rendahnya efisiensi dan pendapatan petani (Supadi, 2005)

Tulisan ini bertujuan mengindentifikasi dan menganalisis 1) keragaan dan struktur biaya usahatani dan 2) tingkat efisiensi dan profitabilitas usahatani tanaman pangan utama (padi, jagung dan kedelai). Diharapkan hasilnya dapat memberikan informasi yang berguna bagi pihak-pihak yang terkait.

\section{METODOLOGI}

Penelitian ini memanfaatkan data yang sudah ada. Data tidak digali dari hasil penelitian sendiri, tetapi berasal dari pengumpulan data yang dilakukan oleh pihak lain atau lembaga. Data tersebut sudah didokumentasikan dan atau dipublikasikan oleh orang lain. Melakukan penelitian analisis data sekunder dapat dilakukan dengan dua pendekatan (Sarah Boslaugh, 2007:6-8). Pertama, dimulai dengan pertanyaan penelitian (rumusan masalah) kemudian dilanjutkan dengan mengumpulkan data sekunder yang relevan. Pendekatan yang kedua, dimulai dengan mengumpulkan data sekunder, lalu menelaahnya untuk mencermati variabel-variabel (aspek- 
aspek) apa saja yang ada dalam data tersebut untuk kemudian dimunculkan pertanyaan penelitian (rumusan masalahnya) dengan menghubunghubungkan berbagai aspek (variabel) tersebut. Pada penelitian ini, pendekatan kedua yang mendasari.

\section{Jenis dan Analisis Data}

\section{Jenis Data}

Data yang digunakan terutama data sekunder yang bersumber dari Badan Pusat Statistik. Adapun langkah-langkah penelitiannya sebagai berikut (Tatang M. Amirin, 2015):

1.Menetapkan (mencari/menemukan) sumber data/informasi, yang berasal dari Badan Pusat Statistik (BPS).

2. Mengumpulkan data yang sudah tersedia (dalam "dokumen"). Dalam hal ini, data terdapat dalam publikasi BPS yang telah diterbitkan berupa laporan survei dan laporan bulanan.

3. Menormalisasikan data jika diperlukan dan memungkinkan (membuat data dari berbagai sumber sesetara mungkin "menjadi satu bentuk yang sama"); Dalam hal ini, beberapa hasil penelitian yang terkait dengan tujuan penelitian telah direferensi dalam tulisan/jurnal ini.
4. Menganalisis data (misalnya menghitung, mentabulasi, memetakan data-data kuantitatif, atau membandingkan berbagai peraturan dan menelaahnya). Dalam hal ini, penulis telah mereferensi pula landasan teori dan teknik analisis data yang relevan dengan tulisan/jurnal ini.

\section{Analisis Data}

Analisis struktur biaya usahatani dilakukan dengan menghitung komposisi biaya dari masing-masing komponen input usahatani. Selanjutnya dilakukan analisis profitablitas dan efisiensi usahatani dari masing-masing komoditas.

Penghitungan struktur biaya usahatani dilakukan dengan menggunakan formula sebagai berikut:

$$
\begin{aligned}
& \text { TCi n } \\
& \text { CSi = ------- } \text { x 100\% dan } \Sigma \mathrm{CSi}=100 \\
& \Sigma \mathrm{TCi} \quad \mathrm{i}=1
\end{aligned}
$$

dimana:

$\mathrm{CSi}=$ pangsa biaya input ke $\mathrm{i}$

$\mathrm{TC} \mathrm{i}$ = biaya input ke $\mathrm{i}$

$\mathrm{TC}=$ biaya total

Keuntungan usahatani dihitung dengan

formula:

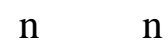

1). $\pi=\mathrm{TR}-\mathrm{TC}=\mathrm{PQ}-(\Sigma \mathrm{TC}+\Sigma \mathrm{PiXi})$

$$
\mathrm{i}=1 \quad \mathrm{I}=1
$$

keterangan:

$\pi=$ keuntungan 
$\mathrm{TR}=$ total penerimaan

$\mathrm{TC}=$ total biaya

$\mathrm{P}$ = harga output

$\mathrm{Q}=$ jumlah output

$\mathrm{Pi}=$ harga input ke $\mathrm{i}$

$\mathrm{Xi}=$ jumlah input ke $\mathrm{n}$

Kriteria, bila $\pi>0$ usahatani

menguntungkan $\pi<0$ usahatani tidak menguntungkan

2). Efisiensi usahatani dhitung dengan formula:

$$
\mathrm{E}=(\pi / \mathrm{TR}) \times 100 \%
$$

$\mathrm{R} / \mathrm{C}$ Ratio $=\mathrm{TR} / \mathrm{TC}$

Kriteria bila R/C > 1, usahatani layak $\mathrm{R} / \mathrm{C}<1$, usahatani tidak layak

\section{HASIL DAN PEMBAHASAN \\ Struktur Biaya Usahatani}

Secara keseluruhan, pangsa biaya terbesar untuk tanaman padi, jagung dan kedelai adalah upah pekerja disusul sewa lahan. Proporsi upah pekerja untuk ketiga komoditi tersebut dari tahun 2011 ke tahun 2014 cenderung menurun, sedangkan sewa lahan cenderung mengalami kenaikkan dari tahun 2011 ke tahun 2014. Total biaya padi, jagung, dan kedelai cenderung mengalami penurunan dari tahun 2011 ke tahun 2014. Penurunan total biaya ini karena terjadinya penurunan yang cukup signifikan pada upah kerja, meskipun ada kenaikan sewa lahan, tetapi delta kenaikannya masih di bawah delta penurunan upah kerja. Struktur biaya pada data sekunder BPS ini sedikit berbeda dengan dengan hasil penelitian Supadi (2005). Struktur biaya pada data BPS memperhitungkan sewa lahan, sedangkan pada Supadi (2005) tidak memperhitungkan sewa lahan. Dalam penelitian Warsana (2007), sewa lahan juga tidak dimasukkan dalam analisis, tetapi pajak lahan pertanian diperhitungkan dalam analisis. Menurut Mubyarto (1999) dalam Warsana (2007), faktor produksi tanah bersama faktor produksi yang lain yaitu tenaga kerja dan modal bersama-sama dalam usahatani digunakan untuk memperoleh pendapatan dan untuk mempertahankan pendapatan keluarga tani.

\section{Padi Sawah}

Pangsa biaya terbesar untuk tanaman padi secara umum adalah upah pekerja dan sewa lahan., baik pada tahun 2011 maupun pada tahun 2014. Namun demikian, upah pekerja ini menurun dari tahun 2011(Rp 4,9 juta atau 38,29\%) ke tahun 2014 ( $\operatorname{Rp~4,5~juta~atau~35,90\% ),~}$ sedangkan untuk sewa lahan justru mengalami kenaikan dari tahun 2011 (Rp 3,3 juta atau 25,64\%) ke tahun 2014 (Rp 
3,8 juta atau 29,90\%), seperti yang kegiatan perontokan menggunakan mesin ditunjukkan dalam tabel 1 dan tabel2. tresher, dan lain-lain, sehingga terjadi Upah kerja yang menurun ini mungkin efisiensi biaya. Sewa lahan yang disebabkan, antara lain sebagian tenaga cenderung naik, antara lain karena manusia telah digantikan dengan mesin, ketersediaan lahan yang makin terbatas, misalnya kegiatan tanam menggunakan baik luasannya maupun persaingan mesin transplanter, kegiatan panen penggunaannya.

menggunakan mesin combine harvester,

Tabel 1. Nilai Produksi dan Biaya Produksi per Musim Tanam per Hektar Budidaya Tanaman Padi Sawah, Padi Ladang, Jagung, dan Kedelai, tahun 2011

\begin{tabular}{|c|c|c|c|c|c|c|c|c|}
\hline \multirow[b]{2}{*}{ Uraian } & \multicolumn{2}{|c|}{ Padi Sawah } & \multicolumn{2}{|c|}{ Padi Ladang } & \multicolumn{2}{|c|}{ Jagung } & \multicolumn{2}{|c|}{ Kedelai } \\
\hline & $\begin{array}{l}\text { Nilai } \\
\text { (Juta } \\
\text { Rupiah) }\end{array}$ & $\%$ & $\begin{array}{l}\text { Nilai } \\
\text { (Juta } \\
\text { Rupiah) }\end{array}$ & $\%$ & $\begin{array}{l}\text { Nilai } \\
\text { (Juta } \\
\text { Rupiah) }\end{array}$ & $\%$ & $\begin{array}{l}\text { Nilai } \\
\text { (Juta } \\
\text { Rupiah) }\end{array}$ & $\%$ \\
\hline B. Biaya Produksi & & & & & & & & \\
\hline 1. Bibit/Benih & 536,26 & 4,11 & 497,05 & 4,82 & 679,01 & 6,78 & 539,06 & 5,50 \\
\hline 2. Pupuk & $1.844,41$ & 14,13 & $1.375,50$ & 13,34 & $1.666,27$ & 16,64 & $1.085,54$ & 11,08 \\
\hline 3. Pestisida & 280,68 & 2,15 & 147,77 & 1,43 & 138,34 & 1,38 & 266,12 & 2,72 \\
\hline 4. Upah Pekerja & $4.998,47$ & 38,29 & $5.344,12$ & 51,81 & $4.507,66$ & 45,01 & $4.967,58$ & 50,69 \\
\hline 5. Jasa Pertanian & $1.048,91$ & 8,03 & 505,06 & 4,90 & 514,44 & 5,14 & 377,47 & 3,85 \\
\hline 6. Sewa lahan & $3.347,87$ & 25,64 & $1.803,56$ & 17,48 & $1.945,53$ & 19,43 & $2.145,32$ & 21,89 \\
\hline 7. Sewa Alat /sarana & 531,95 & 4,07 & 386,96 & 3,75 & 253,61 & 2,53 & 181,29 & 1,85 \\
\hline Usaha & 466,47 & 3,57 & 254,93 & 2,47 & 309,79 & 3,09 & 238,36 & 2,43 \\
\hline 8. Lainnya & & & & & & & & \\
\hline Total Biaya Produksi & $13.055,02$ & 100,00 & $10.314,95$ & 100,00 & $10.014,65$ & 100,00 & $9.800,74$ & 100,00 \\
\hline
\end{tabular}

Sumber : Publikasi Statistik Indonesia

Tabel 2. Nilai Produksi dan Biaya Produksi per Musim Tanam per Hektar Budidaya Tanaman Padi Sawah, Padi Ladang, Jagung, dan Kedelai, tahun 2014

\begin{tabular}{|c|c|c|c|c|c|c|c|c|}
\hline \multirow[t]{2}{*}{ Uraian } & \multicolumn{2}{|c|}{ Padi Sawah } & \multicolumn{2}{|c|}{ Padi Ladang } & \multicolumn{2}{|c|}{ Jagung } & \multicolumn{2}{|c|}{ Kedelai } \\
\hline & $\begin{array}{l}\text { Nilai } \\
\text { (Juta } \\
\text { Rupiah) }\end{array}$ & $\%$ & $\begin{array}{l}\text { Nilai } \\
\text { (Juta } \\
\text { Rupiah) }\end{array}$ & $\%$ & $\begin{array}{l}\text { Nilai } \\
\text { (Juta } \\
\text { Rupiah) }\end{array}$ & $\%$ & $\begin{array}{l}\text { Nilai } \\
\text { (Juta } \\
\text { Rupiah) }\end{array}$ & $\%$ \\
\hline A. Nilai Produksi & 17,2 & & 10,3 & & 12,0 & & 9,0 & \\
\hline B. Biaya Produksi & 12,7 & 100,00 & 7,8 & 100,0 & 9,1 & 100,00 & 9,1 & 100,00 \\
\hline 1. Bibit/Benih & 0,4 & 3,20 & 0,3 & 3,60 & 0,7 & 8,00 & 0,6 & 6,90 \\
\hline 2. Pupuk & 1,3 & 10,40 & 0,6 & 7,80 & 1,1 & 12,00 & 0,4 & 4,80 \\
\hline 3. Pestisida & 0,2 & 1,90 & 0,1 & 1,70 & 0,1 & 1,20 & 0,2 & 2,20 \\
\hline 4. Upah Pekerja & 4,4 & 35,90 & 4,6 & 58,80 & 3,7 & 40,90 & 3,6 & 39,90 \\
\hline a. Pemgolahan Lahan & 1,0 & 7,60 & 1,3 & 17,00 & 0,9 & 9,80 & 0,7 & 7,50 \\
\hline b. Penanaman dan & 0,9 & 7,50 & 1,0 & 12,20 & 0,7 & 7,20 & 0,7 & 8,00 \\
\hline Penyulaman & 0,8 & 6,20 & 0,7 & 8,70 & 0,6 & 6,60 & 0,5 & 5,90 \\
\hline c. Pemeliharaan & 0,3 & 2,30 & 0,2 & 2,20 & 0,4 & 4,00 & 0,2 & 1,90 \\
\hline $\begin{array}{l}\text { d. Pemupukan } \\
\text { e. Pengendalian OPT }\end{array}$ & 0,3 & 2,30 & 0,1 & 1,80 & 0,1 & 1,10 & 0,3 & 2,70 \\
\hline f. Pemanenan, & 1,3 & 10,30 & 1,3 & 16,90 & 1,1 & 12,20 & 1,3 & 13,90 \\
\hline
\end{tabular}




\begin{tabular}{|l|r|r|r|r|r|r|r|r|}
\hline \multicolumn{1}{|c|}{ Perontokan, dan } & 1,6 & 12,40 & 0,3 & 3,50 & 0,4 & 4,00 & 0,4 & 4,90 \\
Pengangkutan & 3,8 & 29,90 & 1,4 & 17,70 & 2,5 & 27,70 & 3,3 & 35,60 \\
5. Jasa Pertanian & 0,3 & 2,60 & 0,2 & 2,20 & 0,2 & 1,90 & 0,2 & 1,80 \\
6. Sewa lahan & 0,1 & 0,70 & 0,1 & 0,90 & 0,1 & 0,90 & 0,1 & 0,80 \\
7. Sewa Alat/sarana Usaha & 0,4 & 3,20 & 0,3 & 3,70 & 0,3 & 3,40 & 0,3 & 3,10 \\
8. Bahan bakar & & & & & & & & \\
9. Lainnya. & 12,7 & 100,00 & 7,8 & 100,00 & 9,1 & 100,00 & 9,1 & 100,00 \\
& & & & & & & & \\
Total Biaya Produksi & & & & & & & & \\
\hline
\end{tabular}

Sumber : Publikasi Statistik Indonesia

\section{Padi Ladang}

Seperti halnya padi sawah, pangsa biaya terbesar untuk tanaman padi ladang secara umum adalah upah pekerja dan sewa lahan., baik pada tahun 2011 maupun pada tahun 2014. Upah pekerja menurun secara nominal dari tahun 2011(Rp 5,3 juta) ke tahun 2014 (Rp 4,6 juta), tetapi naik secara persentase dari tahun 2011(51,81\%) ke tahun 2014 (58,80\%), sedangkan untuk sewa lahan mengalami penurunan juga secara nominal dari tahun 2011 (Rp 1,8 juta) ke tahun 2014 (Rp 1,4 juta), tetapi naik secara persentase dari tahun $2011(17,48 \%)$ ke tahun 2014 $(17,74 \%)$.

\section{Jagung}

Pangsa biaya terbesar untuk tanaman jagung secara umum adalah upah pekerja dan sewa lahan., baik pada tahun 2011 maupun pada tahun 2014. Namun demikian, upah pekerja ini menurun dari tahun 2011(Rp 4,5 juta atau 45,01\%) ke tahun 2014( Rp 3,7 juta atau 40,90\%), sedangkan untuk sewa lahan justru mengalami kenaikan dari tahun 2011 (Rp 1,9 juta atau 19,43\%) ke tahun 2014 (Rp 2,5 juta atau 27,70\%). Upah kerja yang menurun ini bisa disebabkan, antara lain sebagian tenaga manusia telah digantikan dengan mesin, bahan kimia dan atau organik, misalnya kegiatan pembersihan/penyiangan gulma menggunakan herbisida baik pra tumbuh maupun pasca tumbuh, perontokkan dan pemipilan jagung menggunakan tresher dan lain-lain, sehingga terjadi efisiensi biaya. Sewa lahan yang cenderung naik, antara lain karena ketersediaan lahan yang makin terbatas, baik luasannya maupun persaingan penggunaannya

\section{Kedelai}

Tidak berbeda dengan tanaman padi dan kjagung, pangsa biaya terbesar untuk tanaman kedelai secara umum adalah upah pekerja dan sewa lahan., baik pada tahun 2011 maupun pada tahun 2014. Namun demikian, upah pekerja ini 
menurun dari tahun 2011(Rp 4,9 juta atau $50,69 \%$ ) ke tahun 2014( Rp 3,6 juta atau $39,90 \%$ ), sedangkan untuk sewa lahan justru mengalami kenaikan dari tahun 2011 (Rp 2,1 juta atau 21,89\%) ke tahun 2014 (Rp 3,3 juta atau 35,60\%). Upah kerja yang menurun ini bisa disebabkan, antara lain sebagian tenaga manusia telah digantikan dengan mesin, bahan kimia dan atau organik, misalnya kegiatan pembersihan/penyiangan

gulma menggunakan herbisida baik pra tumbuh maupun pasca tumbuh, dan lain-lain, sehingga terjadi efisiensi biaya. Sewa lahan yang cenderung naik, antara lain karena ketersediaan lahan yang makin terbatas, baik luasannya maupun persaingan penggunaannya

\section{Profitabilitas Usahatani}

Tabel 3. Analisis Data

\begin{tabular}{|l|c|c|c|c|}
\hline & $\begin{array}{c}\text { Padi Sawah } \\
2014\end{array}$ & $\begin{array}{c}\text { Padi ladang } \\
2014\end{array}$ & Jagung 2014 & Kedelai 2014 \\
\hline Profitabilitas (Juta) & 4,50 & 2,50 & 2,90 & $(0,10)$ \\
\hline R/C & 1,35 & 1.32 & 1,32 & 0,99 \\
\hline Efisiensi (\%) & 26,16 & 24,27 & 24,27 & $(1,1)$ \\
\hline
\end{tabular}

\section{Padi Sawah}

Berdasarkan analisis data pada tabel 3 , pada tahun 2014, rata-rata tingkat keuntungan padi sawah sebesar Rp 4,5 26,16\%.

juta per hektar per musim yang diperoleh dari total penerimaan sebesar Rp 17,2 juta per hektar per musin dikurangi dengan total biaya yang dikeluarkan sebanyak $\mathrm{Rp}$ 12,7 juta per hektar per musim. Pada kondisi ini, usahatani padi sawah masih layak dilaksanakan, karena $\mathrm{R} / \mathrm{C}$ ratio di atas atau lebih besar dari 1 yaitu 1,35. Artinya korbanan biaya sebesar Rp 1 dapat mendatangkan penerimaan sebesar Rp 1,35. Layaknya usahatani padi sawah pada tahun 2014, juga didukung perhitungan bahwa usahatani tersebut efisien dengan angka efisiensi sebesar

\section{Padi Ladang}

Pada tahun 2014, rata-rata tingkat keuntungan padi ladang sebesar Rp 2,5 juta per hektar per musim yang diperoleh dari total penerimaan sebesar Rp 10,3 juta per hektar per musin dikurangi dengan total biaya yang dikeluarkan sebanyak $\mathrm{Rp}$ 7,8 juta per hektar per musim. Pada kondisi ini, usahatani padi ladang masih layak dilaksanakan, karena $\mathrm{R} / \mathrm{C}$ ratio di 
atas atau lebih besar dari 1 yaitu 1,32. Artinya korbanan biaya sebesar $\mathrm{Rp} 1$ dapat mendatangkan penerimaan sebesar $\mathrm{Rp}$ 1,32. Usahatani padi ladang layak dilaksanakan, karena hasil perhitungan pada tahun 2014 menunjukkan angka efisiensi sebesar $24,27 \%$.

\section{Jagung}

Pada tahun 2014, rata-rata tingkat keuntungan jagung sebesar Rp 2,9 juta per hektar per musim yang diperoleh dari total penerimaan sebesar $\mathrm{Rp} 12,0$ juta per hektar per musin dikurangi dengan total biaya yang dikeluarkan sebanyak $\mathrm{Rp} 9,1$ juta per hektar per musim. Pada kondisi ini, usahatani jagung masih layak dilaksanakan, karena $\mathrm{R} / \mathrm{C}$ ratio di atas atau lebih besar dari 1 yaitu 1,32. Artinya korbanan biaya sebesar $\mathrm{Rp} 1$ dapat mendatangkan penerimaan sebesar $\mathrm{Rp}$ 1,32. Usahatani jagung layak dilaksanakan pada tahun 2014, karena hasil perhitungan menunjukkan angka efisiensi sebesar $24,17 \%$.

\section{Kedelai}

Pada tahun 2014, rata-rata tingkat keuntungan usahatani kedelai sebesar minus Rp 0,1 juta per hektar per musim, artinya usaha tani kedelai pada tahun 2014 rugi. Kerugian ini karena total penerimaan sebesar Rp 9,0 juta per hektar per musin lebih rendah dari total biaya yang dikeluarkan sebanyak Rp 9,1 juta per hektar per musim. Penyebab total penerimaaan rendah bisa dikarenakan produksi per hektar rendah, harga jual rendah, input terlalu banyak, harga input terlalu mahal, dan lain-lain. Pada kondisi ini, usahatani kedelai tidak layak dilaksanakan, karena $\mathrm{R} / \mathrm{C}$ ratio di bawah atau lebih kecil dari 1 yaitu 0,99. Artinya korbanan biaya sebesar Rp 1 hanya dapat mendatangkan penerimaan sebesar $\mathrm{Rp}$ 0,99. Oleh karena itu, usahatani kedelai ini pada tahun 2014 tidak efisien, sebagaimana ditunjukkan dengan hasil perhitungan angka efisiensi yang negatif.

\section{KESIMPULAN}

1. Struktur biaya produksi usahatani pada ketiga komoditas pangan utama, yaitu padi, jagung dan kedelai relatif sama dengan proporsi terbesar pada upah, disusul sewa lahan pada periode penelitian tahun 2011 dan tahun 2014.

2. Selama periode penelitian, proporsi (persentase) upah kerja pada usahatani padi sawah, jagung, dan kedelai cenderung turun dari tahun 2011 ke tahun 2014, sedangkan pada usahatani padi ladang naik. 
3. Selama periode penelitian, porporsi (persentase) sewa lahan pada usahatani padi sawah, padi ladang, jagung, dan kedelai cenderung naik dari tahun 2011 ke tahun 2014.

4. Total biaya usahatani padi (sawah dan ladan), jagung, dan kedelai cenderung mengalami penurunan dari tahun 2011 ke tahun 2014.

5. Selama periode penelitian, usahatani yang layak diusahakan adalah padi sawah, padi ladang, dan jagung

6. Apabila pemerintah mempunyai program swasembada kedelai, maka hal-hal yang perlu diperhatikan, antara lain adalah kebijakan harga jual kedelai dan harga input yang kompetitif agar petani mau menanam kedelai.

\section{DAFTAR PUSTAKA}

Boslaugh, Sarah. (2007). Secondary Data Sources for Health: A Practical Guide. Cambridge: Cambridge University Press. [Excerpt published online: "I An Introduction to Secondary Data Analysis"] dalam Tatang $\mathrm{M}$. Amirin's Blog: A Blog of Yogyakarta State-University's blog, , (2015), "Metode Penelitian Sekunder (Analisis Data Sekunder)"

BPS, (2016), "Laporan Bulanan Data Sosial Ekonomi", Edisi Oktober 2016.
BPS, (2011), Struktur Ongkos Usahatani Tanaman Pangan 2011"

Hadi Sapoetro S. (1973). Biaya dan Pendapatan di Dalam Usahatani. Depertemen Ekonomi

Pertanian. Fakultas Pertanian UGM. Yogyakarta dalam Supadi, 2005, "Struktur Biaya Dan Profitabilitas Usahatani Tanaman Pangan (Kasus Desa-Desa Patanas) The Structure Of The Cost And The Profitability Of The Farming Of The Food Crop (The Case Of Patanas Villages), Pusat Analisis Sosial Ekonomi dan Kebijakan Pertanian Bogor

Supadi, (2005), "Struktur Biaya Dan Profitabilitas Usahatani Tanaman Pangan (Kasus Desa-Desa Patanas) The Structure Of The Cost And The Profitability Of The

Farming Of The Food Crop (The Case Of Patanas Villages), Pusat Analisis Sosial Ekonomi dan Kebijakan Pertanian Bogor

Tatang M. Amirin's Blog: A Blog of Yogyakarta State-University's blog, ,(2015), "Metode Penelitian Sekunder (Analisis Data Sekunder)”

Shanner H.W. (1982). Farming System Research and Development Guidelines for Developing Countries. West View Press. Colorado, USA dalam Supadi, 2005, "Struktur Biaya Dan Profitabilitas Usahatani Tanaman Pangan (Kasus Desa-Desa Patanas) The Structure Of The Cost And The Profitability Of The

Farming Of The Food Crop (The Case Of Patanas Villages), Pusat Analisis Sosial Ekonomi dan Kebijakan Pertanian Bogor

Warsana (2007). Analisis Efisiensi Dan Keuntungan Usaha Tani Jagung 
(Studi Di Kecamatan Randublatung Kabupaten Blora). TESIS S2 pada program Magister Ilmu Ekonomi Studi Pembangunan Universitas Diponegoro, Semarang. 